\title{
Capital Structure and Its Role on Performance of Microfinance Institutions: The Ugandan Case
}

\author{
Haruna Sekabira ${ }^{1}$ \\ ${ }^{1}$ Department of Agribusiness and Natural Resource Economics, School of Agricultural Sciences, Makerere \\ University, Uganda \\ Correspondence: Haruna Sekabira, Department of Agribusiness and Natural Resource Economics, School of \\ Agricultural Sciences, Makerere University, Uganda. Tel: 256-752-529-082. E-mail: shvp07@yahoo.co.uk, \\ haruna.sekabira@gmail.com
}

Received: January 28, 2013 Accepted: May 10, 2013 Online Published: May 17, 2013

doi:10.5539/sar.v2n3p86

URL: http://dx.doi.org/10.5539/10.5539/sar.v2n3p86

\begin{abstract}
Micro Finance Institutions (MFIs) rejuvenate economic prowess in developing countries, after severe shocks like wars, droughts and floods. MFIs are a promising tool to tackle poverty and improve food security. Sustainability of MFIs based on their capital structure ensures sustainability in poverty reduction and improved food security. The limited literature on the impacts of capital structures on MFI performance necessitated the study. Panel data from 14 MFIs was collected based on availability and accessibility. The sources of data were financial and income statements covering five years. Econometric analysis using STATA software was done following methodologies of Bogan and Rosenberg. MFIs lent to both individuals and groups and $79 \%$ were not regulated by the Central Bank, $86 \%$ had their funding sources as loans, grants, excluding deposits/savings and $73 \%$ attained operational self-sufficiency. Debt and grants were negatively correlated to operational and financial sustainability. When sustainability was more constricted to financial sustainability, debt and share capital remained noteworthy. Other than grants, debt was paid back on competitive market interest rates most especially debts from money lenders, whereas share capital fetched in revenues to the MFIs at market interest rates from the borrowers. Grants and debt had a substantialdamagingconsequence on MFI performance. Capital structure was essential in MFIs' sustainability. MFI specific characteristics, like management were also important. Subject to sampling uncertainties, the results indicate that adding to regulation by Central Bank, MFIs must specialize their lending to reduce portfolio at risk. MFIs must reduce dependence on debts and grants and resort to accumulating share capital for long-term sustainability.
\end{abstract}

Keywords: microfinance, MFIs, financial sustainability, grants, debts, share capital

\section{Introductory Background}

MFIs globally assist the poor to get access to capital and escape persistent poverty (Ayayi, 2012; Valadez \& Buskirk, 2012). However in some instances in the developing countries like Uganda and others in the Sub Sahara and Eastern Europe, MFIs are also known to confiscate the poor's properties especially on failure to re-pay (Sheremenko, Escalante, \& Florkowski, 2012). Sheremenko et al. (2012) adds that though outreach contributes to MFI sustainability, if outreach is focused to inappropriate targets of the poor, outreachrenders MFIs an enemy of the non-informed community who spread MFI damaging opinions to other community members, limiting potential business clients. In Uganda, the MFIs sector every year suffers an excess of $25 \%$ drop-outs of clients, (Wright et al., 1998). However, other than outreach, decent portfolio quality, active management and the worthy interest rates, established by Bogan, Johnson and Mhlanga (2007), Ayayi and Sene (2010), and Valadez and Buskirk (2012), capital structure composition is also central to MFI sustainability, (Bogan et al., 2007). Sustainable operations of MFIs from 1999, in African countries (Uganda, Benin, Ghana, Ethiopia, Malawi, Burkina Faso, Mozambique and Senegal) had accumulated 2.9 million U.S dollars loan portfolio, 1.6 million U. S dollars savings and advanced 28 rural financial institutions to their independence by 2011 (The Hunger Project (THP), 2013).

Real microfinance operations in Uganda started in the early 1990's with institutions such as FINCA (Charlton et al., 2001). Since the early 1990's to early 2000 's, the Uganda government seriously focused on promotion of MFIs and vigorously championed their participation in the formal financial sector. Around that time, large sums 
of donations were channeled to the poor through MFIs in addition to the gallant government support. However, in 2005, the government strategy changed from MFIs to savings and credit cooperatives (SACCOs) that would be directly controlled without donor's interferences as was with the MFIs (Schmidt, 2012). The change of plan was hugely due to the then looming presidential vote in 2006, after a change in the constitution to remove presidential term limits. Government wished to render her support indirectly to only those who would in return vote for her. This contravened the professional ways of MFIs management and further threatened MFI's sustainability directly (Schmidt, 2012). After 2006, some MFI's still needed close association with both government and donor agencies, thus worked towards transformation to Micro Deposit taking Institutions (MDIs), to avert the direct influence of government but again called for a direct supervision from the central bank. Unfortunately, regulations of the central bank though remained systematic and professional; they restricted MDIs from operating as MFIs thus also limiting the typical MFIs' operations for MDIs. Transformation of some MFIs unreadily to MDI status, further constrained existence of MFIs, (Schmidt, 2012). To sustainably achieve the global goal of lowering poverty among the poor through access to finances, MFIs have to be financially gainful and free from interferences from funding sources, most of which are short-lived, (Ayayi \& Sene, 2010; Ayayi, 2012). Not all MFIs in Uganda would meet the requirements to become MDIs, thus even after 2006, some continued operating as MFIs but interruptedly. Making matters worse, in Uganda there is yet no strict formal regulations for MFIs to assure the security of the interests of their clients (Wright \& Rippey, 2003). Trust from clients is bound around a possibility of long-term existence of an MFI based on its capital composition. A good sustainable capital base also renders an MFI more competitive and hence more beneficial to her clients (Wright \& Rippey, 2003; Porteous, 2009). Therefore assessment of the sustainability of Uganda MFIs based on their capital structure was important.

\subsection{Introduction of the Problem}

Microfinance institutions (MFIs) have extendedlimits of formal finance and involved the deprivedpredominantlyfemales into formal commercial systems thus diversifying families' income bases, physical, humanoid and social assets through decent money managing after economic tremorshence smoothening consumption (Hulme \& Mosley, 1996; Hulme, 1999; Cohen, 2003). Extraordinary operating costs and capital constrictionsin the MFI industry have vetoed MFIs from fulfilling the mammoth demand. Dehejia, Montgomery and Morduch (2005) exhibited that the demand for credit by the deprived is elastic. Hence, great interest rates may limit MFIs capacity to attendto the poorer possibleclienteles. Donor organizations and governments stress financial sustainability as means to exploit outreach breadth (Armend'ariz de Aghion \& Morduch, 2004), urging that MFIs capital structure is critical for their sustainability and performance. Studies on the effect of capital structure for Uganda on firm performance have been insufficient and scarce; such studies have in most cases been done on developed economies. Uhde and Heimeshoff (2009), empirically examined consolidation in banking and financial stability in Europe, Plouffe (2001), identified young and promising MFIs and Mahjabeen (2010) compared provisions of micro loans between MFIs and traditional banks highlighting performances of Japan and United States. Thus, understanding the role of MFIs' capital structure and its composition, whose knowledge largely misses in the literature, constitutes a knowledge gap in Uganda, hence studying the field was important. Mainly this study seeks to ascertain implications of capital structure on MFI performance proxied by sustainability, specifically characterizing indicators of MFI performance, identifying funding sources and then determining the influence of capital structure on MFI performance. Generally the study hypothesized that MFIs with better capital structure would be sustainable, but the question was what nature of such capital structure would render an MFI sustainable operationally and financially. Therefore the study deployed a hierarchal sampling research design of gathering all MFI data from the central governing body of all MFIs where authenticity was more expected and where if gaps existed, the individual MFIs would be approached. Because grants as a composition of capital structure were generated from donors on interest free schemes and given to farmers at a certain interest, this implied that MFIs hugely supported with grants would be more sustainable theoretically. However, practically it implied that such MFIs would operate below the competitive market interest rates as strategy to attract more clients, a matter whose aggregate effect was empirically investigated by this study.

\subsection{Exploration of the Importance of the Problem}

Because much of all the developing economies in Sub-Saharan Africa (SSA) are going formal, they thus need formal ways of accessing financial credit to support their businesses growth (Demirguc-Kunt, Laeven, \& Levine, 2004). Given repetitive catastrophes in SSA including droughts, wars and floods that cause market failures, the number of the poor populations is very high (Stiglitz \& Weiss, 1981). Further the government and private investments are still very limited to establish reasonable commercial banks from which the urban and rural poor 
can access formal financial services to support their businesses (Hartarska, 2005). Because they require a relatively smaller initial capital investment than commercial banks, MFIs have been much promoted by both government and non-government organizations to take financial services to the poor (Armend'ariz de Aghion \& Morduch, 2004). As a generations' wish and goal, success against poverty requires success in MFIs' sustainability to ensure sustainability in household living standards, business growth and economic development (Jalilian \& Kirkpatrick, 2005). Therefore investigation into the core pillars of what makes MFIs sustainable was of paramount importance to guide eradicating poverty.

\subsection{Other Relevant Scientific Issues to the Study}

Other important aspects of MFIs relate to the significance of their environment and their potential for growth based on sustainability.The triumph of a microfinance package - demarcated in statuses of outreach, financial sustainability and/or socio-economic effect - depends on collaboration between program features including the composition of MFIs' capital structure and the context in which it's implemented. The program environment can influence the success and importance of microfinance interventions in two different ways leading to either success or failure.

Principally, socio-economic surroundings may disturb both capacity of clients to profit from loans and their capability to repay. Secondly, the environment unswervingly impacts program operations, for instance by hampering probable range of program events and services offered (Ejigu, 2009). In Uganda, selected MFIs have enjoyed vigorous growth and are nowadays achieving a sizeable amount of clients. Globally the focus must turn on to how the MFIs can sustainably operationally and financially support the growing number of their clients and the widening geographical scope of coverage (Levine, 2004). Certain microfinance services' suppliers in Uganda including; PRIDE, FINCA and Centenary Rural Development Bank are near to financial sustainability or have now surpassed it (Wright et al., 1998). Microfinance amenities contribute to reduced customer vulnerability to economic perils, contributes to firming linkages of clients and their families to the agricultural sector, rejuvenates economic well-being of areas previously under conflict and enables clients to acquire valued skills, (Hoxhaj, 2010; Strand, Kjøllesdal, \& Sitter, 2010; Mori \& Randoy, 2011). Sustainability in development and promotion of MFIs has been viewed as a promising development policy able to address market failures in formal banking systems (Basu, 2005). Since the 1990s, however, MFIs sector has undergone processes towards self-sustainability through attaining formal regulatory status (Robinson, 2001) and some MFIs have transformed completely into banks (Armendariz \& Szafarz, 2009). Modern MFIs are serving a dual objective including reaching the unbanked poor and becoming self-sustainable (Armendariz \& Morduch, 2005; Hartarska, 2005).

\subsection{Research Questions}

According toArmend'ariz de Aghion and Morduch (2005) they concluded that there was a need to increase external funding to support MFIs for the MFIs' role in global poverty reduction. Such funding was usually in terms of grants and debts (loans) that constituted the MFIs' capital structure from which clients were availed the needed formal financial services (Bogan et al., 2007). However with the liberalization of most of the world economies, business sustainability has been much dependent on the firm's ability including MFIs to operate successfully against market forces and at purely established free market forces. The questions for this study was that; what was the role of the various forms of capital structure including grants and loans (debts) on both operational and financial sustainability of MFIs in Uganda.

\section{Method}

\subsection{Participant Characteristics}

Participants in this study were Microfinance institutions (MFIs) in Uganda. In the study research preparations, every financial institution that had a publicly accessible office and was involved in formal delivery of financial services to the public was considered. Such MFIs were supposed to have registered with the Association of Microfinance Institutions in Uganda (AMFiU) and had their relevant financial data availed to AMFiU. Such MFIs had a five year span (2004 to 2008) data available. We used only AMFiU registered MFIs to better assess the status of MFIs performance in Uganda since registration had a required quality performance criterion. The MFI data was collected by AMFiU from distinct institutions as conveyed in their yearly financial reports and audited financial statements. Data was collected from MFIs that were regulated by the Central Bank and non-regulatedones.

\subsection{Sampling Procedures}

There was no systematic sampling procedure used but a plan for a hierarchal sampling design was deployed if data verification was needed. AMFiU was used as the supreme center of research participants but if data 
verification were needed, as usually some MFIs would have some relevant data missing, then we would trickle down to the individual MFIs for verification. All the AMFiU selected and registered 14 MFIs participated in the study. MFIs were drawn from formal, semi-formal, and informal sectors only excluding individual money lenders. There were no payments for access to the data but professional agreements of using the data for only study purposes were a requirement.

\subsubsection{Sample size, Power and Precision}

Since MFIs were not as many as if it were human participants, there was no number targeted for the research, though the study hoped for as much as would be available for better inferences. Use of panel data wasanalytically a powerful tool as its multiplicative effect generated a sample size of 70 participants, though realistically 14 MFIs participated. Each of the 14 MFIs involved was analytically considered five times each representing a year.Bias was eliminated from the sample insofar as MFIs were operating in all regions of Uganda with branches at least at district level except the capital city where some MFIs had more than one branch. Such spread of branches and operations was based on availability of clients and such clients were very different including those with securities and those without, those that borrowed in groups and those that borrowed individually, those that had seasonal businesses like farming and those that had permanent businesses and so on.

\subsubsection{Measures and Covariates}

The data used in the study was mostly secondary collected from yearly financial and income statements of selected MFIs available at AMFiU. Measures included; cash deposits, short term investments, gross loan portfolio, net loan reserve, short term asset, fixed assets, restricted savings, voluntary savings, short term debts, long term debts, liabilities, loans from central bank, differed incomes sources, administrative funds, share capital, reserves, differed income, donated equity, retained surplus, interest income on loans, income from investments, operating income, portfolio at risk, group loans, percentage loans to women clients, number of active borrowers, number of savers, qualifications of staff, average cost per borrower, minimum qualification of directors and provision for loan loss. Observations if necessary were made on special requests to particular MFIs on the same measures. The quality of these measures was good as MFIs followed the reporting procedures and requirements of AMFiU that were established following international guidelines. The data extraction was also done by the authors who are experienced and minimally educated at a master's degree level in applied economics with profound knowledge in agricultural finance. Such knowledge allowed better scrutiny and assessment of the quality and accuracy of the reporting of these financial variables.

\subsubsection{Research Design}

By the limited number of MFIs in Uganda, all that was available at AMFiU is what was observed to capture all representation of semi-formal and formal MFIs' operations in Uganda. We just studied holistically all existing MFIs' financial records for the intended social, operational, and financial variables without any elimination of any particular MFI presented by AMFiU. The data was analyzed to generate descriptive statistics using Special Packages Social Scientists (SPSS) involving calculating means and frequencies, and econometric models were generated using STATA computer packages developed by the World Bank. The smaller numbers of MFIs (14) limited segregation of the data into smaller groups for further group analysis. For instance analysis was unanimous yet it would have been more appropriate to analyse the data depending on categorisation of MFIs (considering different tier levels/categories) based on their assets, reserves, savings, client base and others. Further categorization was impossible due to small real numbers of the sample as this was the only available data. However to capture specific effects of MFIs on their sustainability stemming from the variance in MFIs' management, reserves, assets and others, specific MFI dummies were included in the models. Dummy quantities for each MFI denoted all those other influences specific to the particular MFI but not included among the regressors. For example the kind of management exhibited by the MFI, proximity to trading centres, portfolio quality and others. Because there were several factors observable and non-observable that explained the sustainability of an MFI, dummy variables were used to cater for the non-observable variables and those observable but very marginally impacting, and or those observable but unavailable in the data set since it was a secondary data collected by another institution. Ayayi and Sene (2010) had found that some of these non-available variables in our data set like management, were important to MFI sustainability. A dummy variable was treated as binary in respect to the MFI under consideration. A dummy variable took a value of one (1), if the respective MFI was under consideration and took a value of zero (0) for all the other MFIs at that particular consideration.

\subsubsection{Analytical Framework and Model Specifications}

According to Microfinance Information Exchange, Inc. (MIX) of Washington D.C, cited by Bogan et al. (2007), 
their definitions were used for operational and financial sustainability as measures of performance of MFIs in Uganda as below;

Operational self-sufficiency is defined as:

$$
\frac{\text { totalfinancialrevenue }}{\text { operating expense }+ \text { financial expenses }}
$$

Operational sustainability is demarcated as having an operational self-sufficiency equal to $100 \%$ or more.

Financial sustainability is demarcated as having an operational sustainability equal to $110 \%$ or more. Demarcations are used to guide model specification. However Bogan et al. (2007) chose to use the level of $110 \%$ because it was the recommendation of MIX. However the Africa Microfinance Network, (AFMIN, 2002), explains that financial sustainability is more constricted and a more preferred and reliable measure of MFI's sustainability because unlike operational sustainability, financial sustainability takes care of attributed cost of capital. To more guarantee quality in measurement of MFIs' sustainability, financial sustainability as shown in Equation (4) was finally computed in a more constricted way following Rosenberg (2009) where the effect of grants was isolated from the capital structure. Common explanatory variables are used for Equation (4) as those in Equations 1, 2 and 3.

The primary specification represented by Equation 1 below, is a regression model with panel corrected standard errors constructed to exhibit the connection between operational self-sufficiency level and numerous MFI characteristics and capital structure variables as regressors

$$
\text { OSS }=\beta_{0}+\sum_{i=1}^{5} \beta_{i} X_{i}+\sum_{j=6}^{24} \beta_{j} Y_{j}+\varepsilon
$$

Dependent variable is Operational self-sufficiency, (OSS), Autonomous variables are; Capital Structure variables denoted by $\mathrm{X}_{i}$, spanning from $\mathrm{i}=1$ to 5 including;

$\mathrm{X}_{1}=$ Percent of debt on assets, $\mathrm{X}_{2}=$ Percent of grants on assets, $\mathrm{X}_{3}=$ Percent of share capital on assets, $\mathrm{X}_{4}=$ Percent of total equity on assets and $X_{5}=$ Percent of debt on total equity. Others were MFI characteristics denoted by $Y_{j}$, spanning from $j=6$ to 24 , including; $Y_{6}=$ Logarithm of assets, $Y_{7}=$ Risk cushion measure (Loan loss reserve/Gross loan portfolio), $Y_{8}=$ Logarithm of borrowers, $Y_{9}=$ Logarithm of savers and $Y_{10}=$ Borrowers per credit officer, $Y_{11}$ to $Y_{24}$ were MFI specific dummies capturing MFI fixed effects. Fixed effects enable reflect the response of one MFI in an environment of the others. $\beta_{i}$ and $\beta_{j}$ were parameters for prediction, $\varepsilon$ denoted error terms and $\beta_{0}$ the constant, representing value of OSS, if all considered variables were zero. Other Equations (2) and (3) of a probit regression were specified to study the role of capital structure on performance of MFIs. In these probit models relatively more strict measures of performance were used that included Operational sustainability denoted by Equation (2) and finally the strictest of the three measures; financial sustainability denoted by Equation (3). Similar capital structure and MFI characteristics independent variables as those used in Equation (1) were used in Equations (2) and (3) to fully and further scrutinize the strength of impact of particular capital structure variables on MFIs' performance.

$$
O S S D=\beta_{0}+\sum_{i=1}^{5} \beta_{i} X_{i}+\sum_{j=6}^{24} \beta_{j} Y_{j}+\varepsilon
$$

OSSD is a dummy representing MFIs Operational sustainability, (1 if MFI attained operational sustainability, 0 otherwise), X symbolizes MFI capital structure variables, Y symbolizes MFI characteristic variables, $\beta_{i}$ and $\beta_{j}$ are parameters to be predicted, $\varepsilon$ denoted error terms and $\beta_{0}$ the constant.

$$
F S S D=\beta_{0}+\sum_{i=1}^{5} \beta_{i} X_{i}+\sum_{j=6}^{24} \beta_{j} Y_{j}+\varepsilon
$$

FSSD represents a dummy of MFIs financial sustainability, ( 1 if MFI attained financial sustainability, 0 otherwise), X symbolizes MFI capital structure variables, Y symbolizes MFI characteristic variables, $\beta_{i}$ and $\beta_{j}$ are parameters to be predicted, $\varepsilon$ denoted error terms and $\beta_{0}$ the constant

\section{Results}

\subsection{Descriptive Statistics and Analysis Results}

All MFIs (100\%) lent to both individuals and groups. Combining the lending methodology allowed MFIs increase their chances of getting clients. Only $14.3 \%$ of MFIs comprising only of Rural Credit and Success (Table 2) had deposits/savings contributing over $50 \%$ of their total liabilities, $85.7 \%$ accessed funds from other sources that included loans from commercial banks, central banks, international organizations and grants. 
Majority of MFIs (78.6\%) were not regulated by the Central Bank signaling managerial risks. $64.3 \%$ of MFIs including Pride, Faulu, Ugafode, Rural Credit, Busimbi, Microcredit, PEARL, Success and Uganda M had over $30 \%$ of their total liabilities composed of others (probably grants) and not loans nor savings.

Table 1. The variations in MFIs by their lending methodology and charter type

Source: Author's data.

\begin{tabular}{ll}
\hline Lending Methodology & Percent of Sample \\
\hline -Individual & 0.00 \\
-Group & 0.00 \\
-Individual/Group & 100.00 \\
Charter type & \\
Regulated (MDI) & 21.40 \\
Non-regulated & 78.60 \\
\hline
\end{tabular}

Table 2. Five year average values of composition of liabilities considering MFIs' funding sources

\begin{tabular}{lllcl}
\hline MFIs & \multicolumn{3}{c}{$\begin{array}{l}\text { Total Liabilities } \\
\text { in '000,000 UGX }\end{array}$} & \multicolumn{3}{c}{ Percent of Total Liabilities provided by: } \\
\cline { 4 - 5 } & & Loans & Deposits/Savings & Others \\
\hline Pride & 672,000 & 40.0 & 19.8 & 40.2 \\
Faulu & 138,000 & 34.6 & 21.9 & 43.5 \\
Mednet & 97,532 & 35.7 & 46.1 & 18.2 \\
Ugafode & 42,958 & 0.0 & 29.2 & 70.8 \\
Rural Credit & 7,332 & 18.7 & 50.2 & 31.1 \\
Busimbi & 836 & 28.1 & 37.9 & 34.0 \\
Microcredit & 12,700 & 38.5 & 28.6 & 32.9 \\
Victoria savings & 23,341 & 60.2 & 39.5 & 0.3 \\
Support & 34,518 & 51.0 & 40.7 & 8.3 \\
ISSIA & 9,065 & 48.9 & 33.2 & 17.9 \\
FINCA & 338,524 & 34.0 & 49.3 & 16.7 \\
PEARL & 41,946 & 2.2 & 39.7 & 58.1 \\
Success & 19,542 & 10.3 & 53.2 & 36.5 \\
Uganda M & 466,302 & 32.0 & 36.1 & 31.9 \\
\hline
\end{tabular}

Source: Author's data: UGX is the currency code for Uganda. 2,645 UGX $=1$ U.S dollars.

Note: Uganda M, is Uganda Microfinance Limited (UML) which has now transformed with partners from Kenya to form Equity Bank Uganda.Faulu also recently transformed to Opportunity Bank Uganda whereas Support Uganda has either recently transformed into a SACCO or collapsed as it is currently non-traceable.

Table 3. MFIs capital structure and performance

\begin{tabular}{lllll}
\hline Varlables & Mean Value & Std. Dev. & Min. & Max. \\
\hline Percent of Deposits on Assets & 19.79 & 14.88 & 0.00 & 55.74 \\
Percent of Debt on Assets & 13.46 & 16.62 & 0.00 & 143.86 \\
Percent of Share Capital on Assets & 6.46 & 11.14 & 0.00 & 55.51 \\
Percent of Retained Earnings on Assets & 2.04 & 4.44 & -11.97 & 41.08 \\
Percent of Grants on Assets & 14.82 & 13.78 & -0.94 & 51.19 \\
Active Borrowers (Persons) & 15,714 & 15,973 & 330 & 59,889 \\
Number of Credit Otticers (Persons & 54.95 & 55.1 & 1.0 & 182.0 \\
Savers (persons) & 35,043 & 43,354 & 660 & 202,229 \\
Financially Sustainable (\%) & 52.80 & 50.00 & 0.00 & 100.00 \\
Operationally Sustainable (\%) & 72.80 & 44.50 & 0.00 & 100.00 \\
Unsustainable (\%) & 27.20 & 44.50 & 0.00 & 100.00 \\
Returns on Assets (\%) & 2.05 & 12.02 & -3.03 & 197.68 \\
Portfolio at Risk (\%) & 7.77 & 8.93 & 0.00 & 56.18 \\
Number of Years in Operations & 12.14 & 3.07 & 6.0 & 19.0 \\
Number of Branches & 8.92 & 7.60 & 1.00 & 34.00 \\
\hline
\end{tabular}

Return on Assets is percent of net income after taxes on Assets available at the time.

Portfolio at Risk is percent of total Portfolio at risk on total Gross loan portfolio. Source: Author's data. 
From Table 3, 73\% of MFIs were operationally self-sufficient but only 53\% were financially sustainable, however $27 \%$ of MFIs were unsustainable implying that they were likely to collapse since they were operationally incurring more expenses than the revenues they made.

Table 4. MFIs' capital structure - correlations with MFIs' sustainability

\begin{tabular}{lcc}
\hline MFI Characteristic & \multicolumn{2}{c}{ Correlation with } \\
\cline { 2 - 3 } & Operational Sustainability & Financial Sustainability \\
\hline Percent of debt on Assets & -0.1947 & -0.1883 \\
Percent of Grants on Assets & -0.2437 & -0.1457 \\
Percent of Share Capital on Assets & 0.1883 & 0.2110 \\
Logarithm of Assets & 0.0807 & 0.0186 \\
Risk Cushion Measure & -0.0818 & -0.0331 \\
Total Equity Relative on Assets & -0.1103 & -0.0324 \\
Logarithm of Number of Borrowers & 0.0226 & 0.0622 \\
Logarithm of Number of Savers & -0.0727 & -0.1251 \\
\hline
\end{tabular}

Risk Cushion measure is the ratio of Loan loss reserves on total Gross loan portfolio.

Source: Author's data.

The ratio of share capital on assets was positively correlated to all forms of MFI sustainability.Individual investors operate on competitive market prices, thus enabling MFIs to make better interest revenues that perhaps guarantee sustainability. The numbers of borrowers was positively correlated with both operational and financial sustainability of MFIs, whereas numbers of savers was negatively correlated to both sustainability measures. Risk cushion measure and total assets were negatively correlated to MFIs sustainability. Almost 30\% of MFIs were unsustainable meaning that their expenses were more than their revenues.

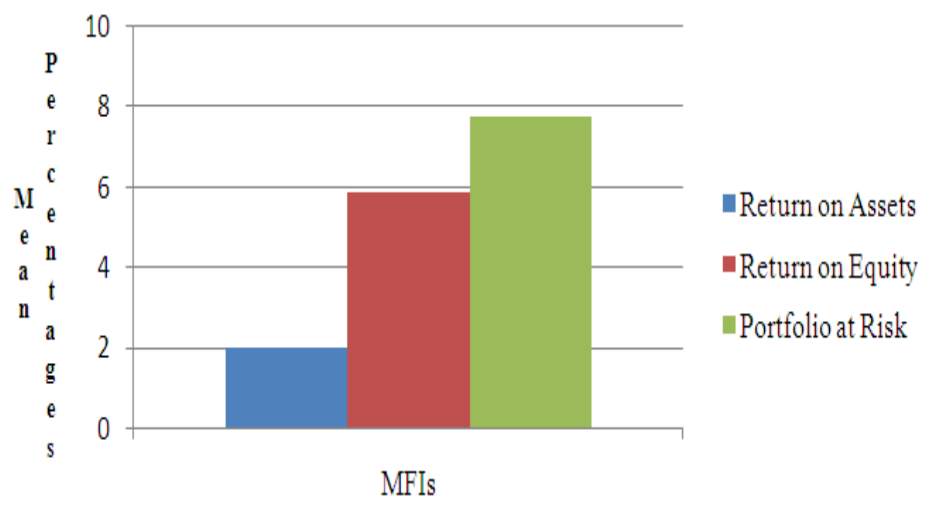

Figure 1. MFIs profitability (Source: Author's data)

Returns on Assets $=\{($ Net Operating Incomes, less taxes $) /($ Period's Total Assets $)\}$

Portfolio at Risk Ratio $=($ Portfolio at risk over 30 days $) /($ Gross Loan Portfolio $)$. Risk greater than 30 days includes all loans that have any of installments of principal and or interest unpaid over 30 days from due date of repayment. Gross loan portfolio, is the total amount of money lent out by the MFI. It excludes loans that with the understanding between the client and the MFI, their repayments have been re-organized.Returns on Equity $=\{(\mathrm{Net}$ Operating Incomes, less taxes)/ (Period's Total Equity of the MFI)\}

Returns on assets though were relatively low, but were better than the average of sub-Saharan Africa (-1\%), but below the world's best, that is Eastern Europe and central Asia (6\%), (Bogan et al., 2007). The return on equity was $5.9 \%$ better than that of Sub-Saharan Africa (2\%) and North Africa (5\%), however it was far below world's best, that is East Asia and the Pacific (16\%) (Bogan et al., 2007). 


\subsection{Econometric Analysis Results}

Table 5. Operational sustainability: Probit regression with marginal effects

\begin{tabular}{|c|c|c|c|}
\hline \multicolumn{4}{|c|}{ Dependent Variable: Operational Sustainability } \\
\hline Independent Variables & Coefficient & Robust Std Errors & Marginal Effects \\
\hline Percent of Debt on Assets & $-0.0443 * * *$ & 0.0134 & -0.0169 \\
\hline Percent of Grantson Assets & $-0.1666 * * *$ & 0.0647 & -0.0638 \\
\hline Percent of Share Capitalon Assets & $0.0462 * * *$ & 0.0157 & 0.0177 \\
\hline Logarithm of Assets & $1.6239 * * *$ & 0.4885 & 0.6218 \\
\hline Risk Cushion Measure & $-3.7491 *$ & 2.0254 & -1.4355 \\
\hline Percent of Total Equity on Assets & -0.0075 & 0.0121 & -0.0029 \\
\hline Logarithm of Numbers of Borrowers & 1.1259 & 1.6718 & 0.4311 \\
\hline Logarithm of Numbers of Savers & -2.2850 & 1.5338 & -0.8749 \\
\hline Per cent of Total debt on Equity & -.11501 & 0.0711 & -0.0441 \\
\hline Borrowers per Credit Officer & 0.0029 & 0.0025 & 0.0011 \\
\hline FAULU & 7.6959 & 9.6053 & 0.6896 \\
\hline MEDNET & 4.5433 & 10.523 & 0.5693 \\
\hline UGAFODE & 6.9057 & 9.3728 & 0.6607 \\
\hline Rural credit & 8.8488 & 8.9171 & 0.7296 \\
\hline Micro Credit & 8.3116 & 8.7815 & 0.7113 \\
\hline SUPPORT & 10.1725 & 8.9932 & 0.7052 \\
\hline ISSIA & 7.3494 & 9.0077 & 0.6771 \\
\hline FINCA & 6.3602 & 10.2017 & 0.6402 \\
\hline PEARL & 7.6358 & 9.6618 & 0.6874 \\
\hline SUCCESS & 5.2567 & 9.4936 & 0.5975 \\
\hline Constant & -32.447 & & \\
\hline
\end{tabular}

No. of Observations $=197$, Pseudo-R2 $=0.4104$, Log pseudo likelihood $=-76.5761 \mathrm{Y}=\operatorname{Pr}$ (Operational Sustainability) $=0.6128,{ }^{*}, * * *$ is significance at $10 \%$ and $1 \%$ level. Source: Author's data.

Percent of Short term Debt on assets and that of total debt on equity were significantly destructively related to operational self-sufficiency, implying that MFIs depending on debts as a source of funding had their efficiency negatively affected. Grants as a percent on assets was significant and depressingly related to MFIs operational self-sufficiency, thus business funds sourced at subsidized interest rates had a negative impact on MFIs efficiency. The logarithm of MFI assets was substantial and positively related to MFI operational self-sufficiency. Bigger financial institutions graded by their asset size were more efficient. This was likened to their possibility to extend financial services to large numbers of clients or these MFIs ability to give out bigger loans to clients. The risk cushion measures were significant and damagingly associated with operational self-sufficiency, implying that regulatory costs incurred to take care of future risks were important, however these costs compromised MFIs efficiency. Such costs were incurred in form of loan loss reserves. All dummies intended to capture MFI specific fixed effects were not significant except for Busimbi and Uganda Microfinance. However all dummies were positively interconnected to operational self-sufficiency, implying that all MFIs' administrations were interested in achieving financial efficiency agreeing with Mersland and Strom, (2007). From Table 6, Logarithm of assets and Percent of share capital on assets were substantial and positively connected to operational sustainability as it were to operational self-sufficiency implying that share capital was important to operationally sustain MFIs. The value of assets to allow MFIs deliver services to their clients was also important in operationally sustaining MFIs, consistent with Cassar and Holmes (2003).

Risk cushion measure was significant and destructivelylinked with operational sustainability, showing that regulatory reserve fees left redundant to cushion future risk negatively impacted on MFI sustainability. Dummies capturing MFI fixed effects were not significant but positively related to operational sustainability, thus MFIs were focused towards operational sustainability. From Table 7, Percent of Share capital on assets was noteworthy and positively related to MFI financial sustainability, stressing the importance of funds sourced from shareholders in MFI financial sustainability. Such funds being part of the capital structure propelled competitive operations in 
MFIs since shareholders wished to earn according to available market interest rates.

Table 6. Financial sustainability: Probit regression with marginal effects

\begin{tabular}{lccc}
\hline \multicolumn{2}{l}{ Dependent Variable: Financial Sustainability } & & \\
\hline Independent Variables & Coefficient & Robust Std Error & Marginal Effects \\
\hline Percent of Debt on Assets & $-0.0278^{* * *}$ & 0.0077 & -0.0110 \\
Grants Relative to Assets & -0.0201 & 0.0381 & -0.0079 \\
Percent of Share Capital on Assets & $0.0191^{*}$ & 0.0115 & 0.0076 \\
Logarithm of Assets & 0.0865 & 0.3064 & 0.0343 \\
Risk Cushion Measure & -0.2295 & 1.6915 & -0.0910 \\
Percent of Total Equity on Assets & 0.0059 & 0.0037 & 0.0024 \\
Logarithm of Numbers of Borrowers & 1.7593 & 1.1593 & 0.6743 \\
Logarithm of Numbers of Savers & -1.0301 & 1.1563 & -0.4086 \\
Per cent of Total Debt on Equity & -0.0024 & 0.0081 & -0.0009 \\
Borrowers per Credit Officer & -0.0004 & 0.0014 & -0.0002 \\
PRIDE & 5.1583 & 5.6127 & 0.5982 \\
FAULU & 5.9627 & 5.2872 & 0.6278 \\
MEDNET & 5.6265 & 5.1058 & 0.6185 \\
UGAFODE & 6.4361 & 5.0759 & 0.6407 \\
Rural credit & 7.1777 & 5.4696 & 0.6607 \\
BUSIMBI & $8.4712^{*}$ & 4.3622 & 0.6944 \\
Micro Credit & 5.1842 & 4.6667 & 0.6062 \\
VICTORIA & 6.8624 & 4.7595 & 0.6429 \\
SUPPORT & 7.2976 & 4.9442 & 0.6243 \\
ISSIA & $7.7838^{*}$ & 4.6828 & 0.6767 \\
FINCA & 4.9339 & 5.4697 & 0.5991 \\
PEARL & 5.5559 & 4.9911 & 0.6165 \\
SUCCESS & 4.6196 & 4.9852 & 0.5903 \\
UGANDA M & 7.6936 & 4.7692 & 0.6978 \\
Constant & -11.985 & & \\
\hline
\end{tabular}

No. of Observations $=275$, Pseudo-R2 $=0.3260, \log$ pseudo likelihood $=-128.1200 \mathrm{Y}=\operatorname{Pr}$ (Financial Sustainability) $=0.5429,{ }^{*}, * *$ is significance at $10 \%$ and $1 \%$ level. Source: Author's data.

Logarithm of assets was not significant but positively interrelated with financial sustainability, showing that the impact of MFI assets was associated positively with sustaining MFIs financially. Dummies of Busimbi and ISSIA MFIs were significant because these were Savings and Credit Co-Operatives (SACCOs) that seriously assessed clients before advancing them funds. However all MFIs were positively allied to financial sustainability, implying that specific MFI characteristics mostly embedded in MFI management were important in sustaining MFIs financially, consistent with Müller and Uhde (2008). MFI specific characteristics like value of assets were important in sustaining MFIs. For instance relying on marginal effects, an increase by $1 \%$ in the logarithm of assets of the MFI, respectively increased MFI operational sustainability by $62 \%$ (Table 6), and financial sustainability by $3.4 \%$ (Table 7). Other than the Bogan et al. (2007) methodology that has been used above, Rosenberg (2009) computes financial self-sustainability as below;

$$
F S S=\frac{\text { TotalOperatingBu } \sin \text { ess RevenueBeforeTaxes }- \text { Grants }}{\text { TotalOperatingExpenses }}
$$

FSS is Financial Self-Sufficiency.

Using Equation (4), and same capital structure and MFI characteristic variables as independents, a Prais Winsten regression was run to determine the impact of capital structure on MFI performance without grants (Financial self-sufficiency) (Table 7). A probit regression dummy for financial self-sustainability in this case similar to financial sustainability defined by Bogan et al. (2007), was also run with same independent variables. MFI whose financial self-sufficiency ratio was one and above were given a value of one and that of 0.99 and below 
zero (Table 8). The Rosenberg (2009) methodology also revealed the role of capital structure on MFI performance. Short term debt, Percent of grants on assets and that of total debt on total equity were significant and negatively correlated with financial self-sufficiency, implying that indeed debts and grants deteriorated MFI efficiency thus their financial sufficiency.

Table 7. Financial self sufficiency prais winsten regression with panel corrected standard errors

\begin{tabular}{lcc}
\hline Dependent Variable: Financial Self Sufficiency & \\
\hline Independent Variables & Coefficient & Standard Error \\
\hline Percent of Short Term Debt on Assets & $-0.0034^{*}$ & 0.0019 \\
Percent of Grants on Assets & $-0.0731^{* * *}$ & 0.0083 \\
Percent of Share Capital on Assets & $0.0073^{* * *}$ & 0.0024 \\
Logarithm of Assets & $0.1593^{* *}$ & 0.0781 \\
Risk Cushion Measure & $1.6177^{* * *}$ & 0.4986 \\
Percent of Total Equity on Assets & $0.0059^{* * *}$ & 0.0008 \\
Logarithm of Numbers of Borrowers & 0.4451 & 0.3195 \\
Logarithm of Numbers of Savers & -0.2904 & 0.3426 \\
Per cent of Total Debt on Equity & $-0.0071^{* *}$ & 0.0028 \\
Borrowers per Credit Otticer & $0.0011^{* * *}$ & 0.0003 \\
PRIDE & -0.2347 & 0.6457 \\
FAULU & 0.5125 & 0.5588 \\
MEDNET & 0.9193 & 0.6098 \\
UGAFODE & 0.4845 & 0.4663 \\
Rural credit & 0.6298 & 0.4182 \\
BUSIMBI & $1.4244^{* * *}$ & 0.4296 \\
Micro Credit & 0.6561 & 0.4365 \\
VICTORIA & 0.3343 & 0.4128 \\
SUPPORT & 0.7825 & 0.5414 \\
ISSIA & $0.7072^{*}$ & 0.4036 \\
FINCA & -0.1407 & 0.6423 \\
PEARL & -0.0257 & 0.4974 \\
SUCCESS & 0.0239 & 0.4682 \\
UGANDA M & 0.5274 & 0.6105 \\
Constant & -4.9177 & 1.4629 \\
Rhos & 0.2380 & 0.3629 \\
\hline I & -0.7841, &
\end{tabular}

No. of Groups $=14$, Observations Per Group $=20$, R-Squared $=0.7841$, Wald chi2(24) $=724.50$, Prob $>$ Chi2 $=$ $0.0000 . * * *, * * *$ is significance at $10 \%, 5 \%$ and $1 \%$ level. Source: Authors' data.

Percent of Share capital on assets and that of total equity on assets (Table 8) were significant and positively associated with financial self-sufficiency, further demonstrating that if an MFI was run with its owners' capital and equity, its sufficiency improved, consistent with Navajas, Conning and Gonzalez (2003). MFI dummies continued to be positively related with financial self-sufficiency, further confirming that MFIs' management varied in interacting capital structure and MFI characteristics but aimed at efficiency, agreeing with Basu, Blavy and Yulek, (2004). From Table 8, Percent of total debt on assets and that of grants were significant and undesirablyinterconnected with financial self-sustainability, confirming the harmful impact of debts and grants on MFI performance. Debts and grants erode MFI efficiency thus financial sustainability. Percent of Share capital on assets was noteworthy but positively linked with financial self-sustainability. Share capital was used at competitive rates to serve shareholders' interests, leading to increased MFI efficiency, lining with Marimuthu (2009).

Log of assets and number of borrowers per credit officer was significant and positively associated with financial self-sustainability. Assets like vehicles enabled credit officers handle more borrowers thus increasing returns per officer, consistent with both Bogan et al. (2007) and Rosenberg (2009). 
Table 8. Financial self sustainability: Probit regression with marginal effects

\begin{tabular}{|c|c|c|c|}
\hline \multicolumn{4}{|c|}{ Dependent Variable: Financial Sustainability } \\
\hline Independent Variables & Coefficient & Robust Std Errors & Marginal Effects \\
\hline Percent of Short Term Debton Assets & -0.0099 & 0.0120 & -0.0015 \\
\hline Percent of Grants on Assets & $-0.8881 * * *$ & 0.2136 & -0.1317 \\
\hline Percent of Share Capitalon Assets & $0.0789 * * *$ & 0.0171 & 0.0117 \\
\hline Logarithm of Assets & $3.3221 * * *$ & 0.8499 & 0.4925 \\
\hline Risk Cushion Measure & -1.7279 & 1.7269 & -0.2562 \\
\hline Percent of Total Equity on Assets & 0.0066 & 0.0108 & 0.0009 \\
\hline Logarithm of Numbers of Borrowers & -2.4109 & 2.0431 & -0.3574 \\
\hline Logarithm of Numbers of Savers & 0.8078 & 1.7699 & 0.1198 \\
\hline Per cent of Total Debt on Equity & $-0.2534 * * *$ & 0.0823 & -0.0376 \\
\hline Borrowers per Credit Otticer & $0.0041^{*}$ & 0.0023 & 0.0006 \\
\hline FAULU & 5.4757 & 13.999 & 0.1637 \\
\hline MEDNET & -0.2201 & 14.557 & -0.0371 \\
\hline UGAFODE & 4.1538 & 14.267 & 0.1395 \\
\hline Rural credit & 7.6688 & 13.630 & 0.2096 \\
\hline BUSIMBI & 10.602 & 12.567 & 0.2814 \\
\hline Micro Credit & 10.553 & 12.665 & 0.2801 \\
\hline VICTORIA & 8.0853 & 13.094 & 0.2098 \\
\hline SUPPORT & 12.529 & 13.165 & 0.2663 \\
\hline ISSIA & 5.4279 & 13.420 & 0.1628 \\
\hline FINCA & 3.7810 & 14.578 & 0.1331 \\
\hline PEARL & 5.3663 & 13.882 & 0.1616 \\
\hline SUCCESS & 3.7519 & 13.995 & 0.1326 \\
\hline UGANDA M & 3.9478 & 14.588 & 0.1359 \\
\hline Constant & -61.952 & & \\
\hline
\end{tabular}

No. of Observations $=256$, Pseudo-R2 $=0.6175$, Log pseudo likelihood $=-52.3927$ Y $=$ Pr (Financial Self Sustainability $)=0.9203,{ }^{*}, * *$ significance at $10 \%$ and $1 \%$ level. Source: Author's data.

\section{Discussions}

MFIs with a better share capital composition in their capital structure were more associated with sustainability as grants and debts composition sinks such sustainability. The holistic assessment of all kinds of MFIs rather than special categorization due to a small number of MFIs available potentially threated quality of inferences. The sample is relatively strong for the larger institutions and inferences therefore less uncertain. The dummy variables used to capture specific MFI effects that were considered as discrete measures rather than continuous ones also limited exact quantitative prediction. However the use of several analytical methods whose direction of prediction was constant in this study and several earlier studies, empirically proved consistence and reliability of measures used, thus upholding the study credibility for external inferences.

Lending to both individuals and groups enabled MFIs reach a bigger clientele base agreeing with Kereta, (2007). MFIs take money deposits as compulsory savings for security on bigger loans to avert failure to re-pay.Grants rendered MFIs uncompetitive thus compromising their growth and hence sustainability. Percent of Grants on assets averagely was $14.8 \%$ of all MFIs' capital structures, below the African average $(20.5 \%)$ and the World's highest (32\%) found in Middle East and North Africa (Bogan, 2008). Though Uganda has had several scenarios warranting need for foreign aid and grants, such scenarios have always caused an average negative impact on MFIs' sustainability.Percent of Share capital on assets only made $6.5 \%$ of capital structure lower than the African average (10.5\%) and far much below the World's highest (19.5\%) found in Eastern Europe and Central Asia (Bogan et al., 2007). The African average is compositions of many countries in Africa including those with vast natural mineral resources like South Africa which contribute to a high per capita GDP that enables nationals buy shares in such businesses. Countries in Eastern Europe and central Asia also have a better GDP per capita than Uganda (Wikipedia, 2011). The ratio of debt and grants on assets are negatively correlated with both operational and financial sustainability. When MFIs' debts increase it threatens MFI's sustainability as MFI struggles to pay at varying interest rates, thus retarding MFIs' performance (sustainability). When the dependence of MFIs on grants increase, the operations of MFIs become less competitive because grant funds are usually given out to borrowers at a lower interest compared to market rates. The lower interest rate charged on grants reduces the interest revenues made by MFIs, and thus funds for future operations. When MFIs increase their borrowers, they lend out more of their funds thus increasing the size and source for their operations' revenues since MFIs earn 
interest from all borrowers. When savers increase, MFIs pay interest income to savers, thus reducing MFIs' reserves hence threatening MFIs' sustainability, especially if borrowers are relatively fewer as is the case in this study. Reserves put aside to cater for loan losses and assets accumulated, are both not usually actively used in generation of revenues, therefore the more these redundant reserves and assets are accumulated; it threatens MFIs' sustainability. Majority of MFIs being financially sustainable was perhaps due to the fact that private shareholders had joined MFI business. Private shareholders contributed to share capital which MFIs used in their operations. Private investors were also interested in the largest possible returns from their capital investments thus forcing MFIs generate enough revenues from operations hence ensuring MFIs' sustainability financially. Non-financially sustainable MFIs have been surviving on non-interest funds and grants from donor organizations and governments, hence their ability to still operate at zero profits. Uganda has been under several man-made and natural disasters for instance droughts and civil wars with rebel groups like Lord's Resistance Army, Allied Democratic Forces and others. Such disasters have always exposed Uganda to foreign direct aid through grants and donations to help rehabilitate, resettle and revamp endangered communities. The relatively good return on equity compared to the whole of Africa is attributed to financial market liberalization in Uganda, creating a competitive market behavior where investors exploit every opportunity to earn the best from their investments. The portfolio at risk is however higher (7.8\%), compared to that of Sub Saharan Africa (7\%), the highest in the world (Bogan et al., 2007) caused by volatile business environments in Uganda characterized with civil wars and natural disasters.

Debts attained by MFIs were sometimes got from non-regulated sources like money lenders who give out their money to MFIs at exorbitantly high interest rates and short payback periods. Failure to have minimum requirements limited MFIs from accessing business funds from credible sources like commercial banks, agreeing with Kyereboah (2007). MFIs did not have the urge to operate competitively on market interest rates because the burden of their payback load had been reduced when they used grants; also found by Bogan et al. (2007) and Bogan, (2008). A good asset base eased MFI operations including; vehicles to reach out to distant better and capable clients, enforcing recovery and others. A good asset base especially in terms of liquidity allowed MFIs to lend out more funds to all available clients thus avoiding liquidity constraints. Monies used in risk cushion were put aside as insurance, thus MFIs were not using it to generate interest revenue hence negatively impacting on MFIs' efficiency. Busimbi and Uganda microfinance had a better response because these were basically smaller lending institutions called Savings and Credit Co-operatives (SACCOs). The services of SACCOs were exclusive to members and the lending procedures were stricter. When we segregated MFIs into discrete classifications leading to those that were operationally sustainable and those that were not and we ran a probit regression for the classification, results in Table 6 were generated. Percent of Debt and grants on assets were significant and deleteriously related to MFIs' operational sustainability, implying that the source of funds was important in sustaining MFIs operationally, consistent with Bogan et al. (2007). A further strict classification of MFIs considering those that were financially stable and those that were not was generated. Similar capital structure variables and MFI characteristics were run in a probit regression on such financial sustainability (Table 7). Percent of Debt on assets was significant and deleteriously related to financial sustainability, stressing that money borrowed importantly threatened MFI financial sustainability, consistent with Matarirano (2007). Assets enforced recovery and more borrowers per credit officer increased returns per credit officer. Larger loan loss reserves ensured continuity of MFIs' lending operations in case of default, liquidity constraints and late repayments, consistent with Consultative Group to Assist the Poor [CGAP] (2004).

\section{Conclusions}

The sample was relatively small and conclusions should be subject to further study. The sample is however relatively strong for the larger institutions and inferences therefore less uncertain. Without grants, the dependent variable responded better to various independent variables. The negative impact of grants to MFIs' performances was also better reflected when grants were used amongst regressors. In all models grants had a negative significant impact on MFIs performance (sustainability). Therefore composition of Capital Structure is important for MFIs' sustainability operationally and financially whereby grants and debts erode it whereas share capital and assets improve it. Government policy must limit MFI's access to grants and debts. Dire financial need by smallholders must only be solved through direct aid to the needy such as food stamps, universal education, health care and others. Banking policy must premier share capital accumulation by MFIsand their close monitoring by Central Bank. However if terms and conditions under which grants are disseminated change to optimal levels (need to be investigated), grants may have a positive influence on MFI sustainability, though changing grants' terms may seriously jeorpardise short-term objectives and intended purposes of grants. 


\section{Acknowledgements}

I wish to extend my sincere thanks to AMFiU that allowed us access to the data and all MFIs involved in the study. African Economic Research Consortium (AERC) is also appreciated for need operational funds during the study processes. Zainab Sekabira is mostly appreciated for the company and proof readings during the study write-up. I also acknowledge the technical support of Assoc. Prof. B. A. Kiiza. Dr. Van Campenhout Bjorn and Dr. NassulKabunga both of IFPRI-Uganda are also acknowledged for their logistical support

\section{References}

Africa Microfinance Network (AFMIN). (2002). Program to build shared performance indicators and standards: agreed performance indicators and definitions. AFMIN, Abidjan Côte d'Ivoire. Retrieved from http://www.mixmarket.org/sites/default/files/medialibrary/10001.644/AFMIN_Standards_in_English.pdf

Armendariz, B., \& Szafarzk, A. (2009). Microfinance institutions: Are they drifting away from their poverty-reduction mission? In B. Armendariz \& M. Labie (Eds.), The Handbook of Microfinance, London-Singapore.

Armend'ariz de Aghion, B., \& Morduch, J. (2004). Microfinance: Where Do We Stand? In Financial Development and Economic Growth (pp. 135-148). New York, NY: Palgrave Macmillan.

Armend'ariz de Aghion, B., \&Morduch, J. (2005). The Economics of Microfinance. Cambridge, MA: The MIT Press.

Ayayi, A. G., \& Sene, M. (2010). What Drives Microfinance Institution's Financial Sustainability. Journal of Developing Areas, 44(1), 303-324. http://dx.doi.org/10.1353/jda.0.0093

Ayayi, A. G. (2012). Microfinance: A Time to Deliberate. Asian Economic and Financial Review, 2(3), 445-447.

Basu, A., Blavy, R., \& Yulek, M. (2004). Microfinance in Africa: experience and lessons fromselected African countries.working paper no. WP/04/174, IMF, Washington, DC

Basu S. (2005). Securitization and the Challenges Faced in Microfinance. Centre for Microfinance Research Working Paper.

Bogan V., (2008). Microfinance Institutions: Does Capital Structure Matter? Department of Applied Economics and Management, Cornell University, 454 Warren Hall, Ithaca, NY 14853. Retrieved from http://ssrn.com/abstract=1144762

Bogan V., Johnson W., \& Mhlanga N., (2007). Does Capital Structure Affect the Financial Sustainability of Microfinance Institutions? Department of Applied Economics and Management, Cornell University, 454 Warren Hall, Ithaca, NY 14853.

Carlton, A., Manndorff, H., Obara, A., Reiter, W., \& Rhyne, E. (2001). Microfinance in Uganda, L \& R Social Research, Austria.

Cassar, G., \& Holmes, S. (2003). Capital structure and financing of SMEs: Australian evidence. Accounting \& Finance, 43(2), 123-147. http://dx.doi.org/10.1111/1467-629X.t01-1-00085

Cohen, R. D. (2003). The Optimal Capital Structure of Depository Institutions. WILMOTT Magazine, pp. 38-49.

Consultative Group to Assist the Poor [CGAP]. (2004). Financial Institutions with a "Double Bottom Line": Implications for the Future of Microfinance. Consultative Group to Assist the Poor, Occasional Paper No. 8

Dehejia, R., Montgomery, H., \& Morduch, J. (2005). Do Interest Rates Matter? Credit Demand in the Dhaka Slums. New York University, Ithaca, USA.

Demirguc-Kunt, A., Laeven, L., \& Levine, R., (2004). Regulations, Market Structure, Institutions, and the Cost of Financial Intermediation. Journal of Money, Credit and Banking, 36, 593-622. http://dx.doi.org/10.1353/mcb.2004.0045

Ejigu, L. (2009). Performance analysis of sample microfinance institutions of Ethiopia.International NGO Journal, 4(5), 287-298. Retrieved from http://www.academicjournals.org/INGOJ

Hartarska, V. (2005). Governance and performance of microfinance institutions in central and eastern Europe and the newly independent states.World Development, 33, 1627-1648. http://dx.doi.org/10.1016/j.worlddev.2005.06.001

Hoxhaj, R. (2010). Regulation and supervision of microfinance in Albania. Business and Economic Horizons, $2(2), 75-81$. 
Hulme, D., \& Mosley, P. (1996). Finance against poverty, Volume 1, London: Routledge.

Hulme, D. (1999). Impact Assessment Methodologies for Micro-finance: Theory, Experience and Better Practice. Finance and Development Research Program, Working Paper No. 1, University of Manchester, UK.

Jalilian, H., \& Kirkpatrick, C. (2005). Does financial development contribute to poverty reduction? Journal of Development Studies, 41(4), 636-656. http://dx.doi.org/10.1080/00220380500092754

Kereta, B. B. (2007). Outreach and Financial Performance: Analysis of Microfinance Institutions in Ethiopia', National Bank of Ethiopia. Paper presented to the African Economic Conference; United Nations Conference Center (UNCC), Addis Ababa, Ethiopia on the 15-17 November.

Kyereboah, A. C. (2007). The impact of capital structure on the performance of microfinance institutions. The Journal of Risk Finance, 8(1), 56-71. http://dx.doi.org/10.1108/15265940710721082

Levine, R. (2004). The Microeconomic Effects of Different Approaches to Bank Supervision. Working Paper, February 6, University of Minnesota, USA.

Mahjabeen, R. (2010). On the provision of micro loans - microfinance institutions and traditional banks. Journal of economic development, 35(1), 59-73

Marimuthu, M. (2009). Corporate Restructuring, Firm Characteristics and Implications on Capital Structure: an Academic View. International Journal of Business and Management, 4(1), 123-131.

Matarirano, O. (2007). An Investigation into the Impact of Debt Financing on the Profitability of Small Manufacturing Firms in Bulawayo, Zimbabwe. University of Fort Hare, South Africa.

Mersland, R., \& Strom, A. R. (2007). Performance and corporate governance in micro-finance institutions.Agder University College, Kristiansand, Norway.

Mori, N., \& Randoy, T. (2011). Determinants of Board Structure in Microfinance Institutions: Evidence from East Africa. University of Agder, Kristiansand, Norway.

Müller, O., \& Uhde, A. (2008). The Impact of External Governance Quality on the Economic Success of Microfinance Institutions Empirical Evidence. Ruhr-Universität Bochum, Bochum, Germany.

Navajas, S., Conning, J., \& Gonzalez-Vega, C. (2003). Lending Technologies, Competition and Consolidation in the Market for Microfinance in Bolivia. Journal of International Development, 15, 747-770. http://dx.doi.org/10.1002/jid.1024

Plouffe, A. (2001). Identifying Promising MFIs. An Input paper for the UNCDF/SUM and UNDP Africa, Global Meeting on Young and Promising MFIs.

Robinson, M. S. (2001). The Microfinance Revolution: Sustainable Finance for the Poor. World Bank and Open Society Institute.Washington, DC, USA. http://dx.doi.org/10.1596/0-8213-4524-9

Rosenberg, R. (2009). Measuring Results of Microfinance Institutions, Minimum Indicators That Donors and Investors Should Track. Consultative Group to Assist the Poor (CGAP), Washington, DC, USA.

Schmidt, O. (2012). Uganda's microfinance policy regime: An exploration through a political-economy framework, Munich Personal RePEc Archive (MPRA). Retrieved from http://mpra.ub.uni-muenchen.de/42374/

Sheremenko, G., Escalante, C. L., \& Florkowski, J. W. (2012). The Universality of Microfinance Operations Model in Eastern Europe and Central Asia: Financial Sustainability vs. Poverty Outreach. Selected Paper prepared for presentation at the Agricultural \& Applied Economics Association's 2012 AAEA Annual Meeting, Seattle, Washington, August 12-14, 2012.

Stiglitz, J. E., \& Weiss, A. (1981). Credit Rationing in Markets with Imperfect Information. American Economic Review, 71(3), 393-410.

Strand, W. A., Kjøllesdal, K., \& Sitter, N. (2010). Assessing Microfinance: The Bosnia and Herzegovina Case. Managing Global Transitions, 8(2), 145-166.

The Hunger Project (THP). (2013). Microfinance Project in Africa, New York U.S.A. Retrieved from http://www.thp.org/what_we_do/key_initiatives/microfinance/overview?gclid=CNjqnrb7irYCFfLLtAod6zs Atg

Uhde, A., \& Heimeshoff, U. (2009). Consolidation in banking and financial stability in Europe: Empirical evidence. Discussion Papers No. 02: ISSN 1867-6707, Friedrich-Alexander-Universität, Germany. 
Valadez, M. R., \& Buskirk, B. (2012). From Microcredit to Microfinance: a business perspective. Journal of Finance and Accountancy, 1-17.

Wright, A. N. G., Mutesasira, L., Sempangi, H., Hulme, D., \& Rutherford, S. (1998). Drop-outs Amongst Ugandan Microfinance Institutions. MicroSave-Market-led solutions for financial services, Nairobi, Kenya.

Wright A. N. G., \& Rippey, P. (2003). The Competitive Environment in Uganda:Implications for Microfinance Institutions and their Clients. MicroSave-Market-led solutions for financial services, Nairobi, Kenya.

Wikipedia. (2011). WIKIPEDIA, The Free Encyclopedia. Retrieved from: http://en.wikipedia.org/wiki/List_of_countries_by_GDP_(PPP)_per_capita 